Hydrology and Earth System Sciences, 4(1), 65-78 (2000) (C) EGS

\title{
A quasi-three-dimensional model for predicting rainfall-runoff processes in a forested catchment in Southern Finland
}

\author{
H. Koivusalo ${ }^{1}$, T. Karvonen ${ }^{1}$ and A. Lepistö ${ }^{2}$ \\ ${ }^{1}$ Laboratory of Water Resources, Helsinki University of Technology, P.O.Box 5200, FIN-02015 HUT, Finland \\ ${ }^{2}$ Finnish Environment Institute, P.O.Box 140, FIN-00251 Helsinki, Finland \\ e-mail for corresponding author: hkoivusa@water.hut.fi
}

\section{Abstract}

Runoff generation in a forested catchment $\left(0.18 \mathrm{~km}^{2}\right)$ was simulated using a quasi-three-dimensional rainfall-runoff model. The model was formulated over a finite grid where water movement was assumed to be dominantly vertical in the unsaturated soil zone and horizontal in the saturated soil. The vertical soil moisture distribution at each grid cell was calculated using a conceptual approximation to the one-dimensional Richards equation. The approximation allowed the use of a simple soil surface boundary condition and an efficient solution to the water table elevation over the finite grid. The approximation was coupled with a twodimensional ground water model to calculate lateral soil water movement between the grid cells and exfiltration over saturated areas, where runoff was produced by the saturation-excess mechanism. Runoff was an input to a channel network, which was modelled as a nonlinear reservoir. The proposed approximation for the vertical soil moisture distribution in unsaturated soil compared well to a numerical solution of the Richards equation during shallow water table conditions, but was less satisfactory during prolonged dry periods. The simulation of daily catchment outflow was successful with the exception of underprediction of extremely high peak flows. The calculated water table depth compared satisfactorily with the measurements. An overall comparison with the earlier results of tracer studies indicated that the modelled contribution of direct rainfall/snowmelt in streamflow was higher than the isotopically traced fraction of event-water in runoff. The seasonal variation in the modelled runoff-contributing areas was similar to that in the event-water-contributing areas from the tracer analysis.

\section{Introduction}

Catchment response to rainfall and snowmelt has remained an important point of focus in hydrological research. Traditionally, runoff has been partitioned into overland and subsurface flow. The overland flow may occur as infiltration-excess overland flow (Horton, 1933) when rainfall intensity exceeds the infiltration capacity of soil surface layers, as saturation-excess overland flow (Dunne and Black, 1970) over the areas where the soil water storage is filled to capacity, or as return flow where soil water is constrained to exfiltrate over the soil surface (Dunne, 1983; Kirkby, 1988; Bonell, 1993). In general, the infiltrationexcess overland flow is important at times of high rainfall intensities and in areas of semi-arid soils or degraded land (Kirkby, 1985), whereas its contribution is of minor importance in natural land areas with permeable soils and a humid temperate climate (e.g. Bonell, 1993; Lepistö 1994). Dunne (1983) suggested that the saturation-excess overland flow becomes important in thickly vegetated areas with thin soils, high water tables and long, gentle concave hillslopes. Environmental tracer studies from forest areas have suggested that the subsurface flow may dominate storm runoff in a stream (e.g. Sklash and Farvolden, 1979; Pearce et al., 1986; Rodhe, 1987). The runoff mechanisms may not be distinguished in a catchment, but generally runoff production is driven by the saturated soil areas and their dynamic variation, which is the main cause of the nonlinear nature of the catchment response to storm rainfalls (Beven and Wood, 1983; Todini, 1996; Franchini et al., 1996).

Several modelling approaches are available to describe the rainfall-runoff process mathematically. Models using the systems approach, such as those based on time series analysis, describe the relation between rainfall and runoff without considering the physics behind the process explicitly (e.g. Wood and O'Connell, 1985). Conceptual models characterise the rainfall-runoff process by using water storages lumped over a catchment, sub-catchments, or predefined zones (e.g. Bergström and Forsman, 1973; Linsley, 1976; Ye et al., 1997; Bergström and Graham, 1998). The main purpose of such models has been to replicate the measured catchment hydrograph. The internal state variables can be checked by comparison with a sufficient number of measurements averaged over the 
modelled area (Seibert, 1999). Todini (1996) stated that the limitation of conceptual models has been the lack of an adequate representation of the variation of saturated areas within the catchment. To overcome the limitations of the process representation, new parameters can be added to the conceptual models. However, such an increase in the number of degrees of freedom may not improve the model performance significantly in terms of the reproduced hydrograph.

Semi-distributed and truly distributed rainfall-runoff models have been introduced to account for the spatial variability of catchment properties, such as topography, soil hydraulic conductivity and soil moisture (Beven and Kirkby, 1979; Abbott et al., 1986; Beven et al., 1987; Merz and Plate, 1997; Karvonen et al., 1999). The distributed models represent the rainfall-runoff processes on the basis of physically consistent theoretical formulations, which for soil water movement follow the laws of continuity and momentum. For example, the Richards equation (Richards, 1931 ) is used to describe water flow in the unsaturated zone, and Darcian flow is assumed to be valid in describing the horizontal water movement in the saturated soil profile. The differential conservation equations in the distributed models are solved over a selected grid, which is assumed to represent the spatial variability of the catchment properties adequately. The applicability of distributed models has been criticised because of the problems originating from increased data requirements and from scaling, which is associated with the question of how to relate point measurements to the grid-scale effective model parameters (Beven, 1989; Grayson et al., 1992; Woolhiser, 1996). In a distributed modelling system, practical problems arise in the stability and convergence of the numerical solutions, and also in the boundary conditions if the external driving variables undergo rapid changes. In fine-grained materials, the presence of macropores makes the surface boundary conditions as well as the soil water movement difficult to represent using the Richards equation (e.g. Beven and Germann, 1982).

The semi-distributed models attempt to overcome the problems faced by the distributed models by simplifying the process representation and by concentrating on the assumed dominant mechanisms of runoff generation, for example saturation-excess overland flow along a channel network (Beven and Kirkby, 1979; Beven and Wood, 1983; Sivapalan et al., 1987; Todini, 1996). The spatial distribution of hydraulic conductivity or terrain topography serves as an example of properties that can be used to identify the saturated contributing areas systematically. TOPMODEL (Beven and Kirkby, 1979; Beven et al., 1994) uses a topography-based index to predict the extent of the saturated areas and has been used successfully to reproduce the catchment hydrograph. However Franchini et al. (1996) consider the model parameters are not sensitive to the actual topographic index curve, but to the grid size of the digital elevation model. Todini (1996) pointed out that the dynamic variation of the saturated areas could be represented using a probability distribution instead of a topography-based index curve. The ARNO model (Todini, 1996) uses the distribution function approach to account for the spatial variability of soil moisture. The semi-distributed models attempt to represent catchment hydrology without going to three dimensions, although the spatial variability of hydrological processes demands a three-dimensional consideration (Sivapalan et al., 1987). A semi-distributed rainfall-runoff model that simulates only the dominant runoff generation mechanisms and the catchment hydrograph may not be adequate if the model is coupled with a solid or solute transport scheme that needs the spatial distribution of soil water flow velocity as input data.

The purpose of this paper is to present a rainfall-runoff model for predicting spatial variability of soil moisture and runoff production over catchments with relatively small depths of mineral soil (a few metres). The modelling approach takes advantage of the distributed and semidistributed models in representing explicitly the grid-scale soil water movement, and in determining the runoff generation due to dynamic variation of saturated areas. A specific objective was to provide a reasonably simple but realistic approximation to the solution of the Richards equation for vertical soil moisture distribution in the unsaturated zone, which enables calculation of soil water flow velocities as carried out for a cultivated hillslope by Koivusalo et al. (1999). The horizontal flow was described using a two-dimensional differential equation of continuity and Darcy's law as commonly applied in groundwater models. The resulting quasi-three-dimensional model allows prediction of the dynamic variation of the runoffcontributing areas and the separation of the soil water and surface water processes.

\section{Site description and data}

The model was set up for Rudbäck (Fig. 1), a small forested catchment $\left(0.18 \mathrm{~km}^{2}\right)$ in Southern Finland. The elevation varies between $34 \mathrm{~m}$ and $68 \mathrm{~m}$ above sea level and the average slope is $17 \%$. The catchment is located in the hemiboreal vegetation zone and is covered by mature Norway Spruce. The soils are composed of silty and sandy moraines with 3 minor peatland areas (Fig. 2). The depth to the bedrock varies between 0 and $5 \mathrm{~m}$ with an average depth of 1-2 m (Lepistö, 1994; Lepistö, 1996; Lepistö and Kivinen, 1997).

The topography of Rudbäck was modelled by digitizing elevation contours of $2.5-5 \mathrm{~m}$ resolution and by calculating a $20 \times 20 \mathrm{~m}^{2}$ digital elevation model (Fig. 2). The digital elevation model was corrected at the location of the ground water table observation tubes to match strictly with the measured elevation given by a manual levelling. The Finnish Environment Institute had conducted seismic refractions to determine the depth to bedrock along selected 


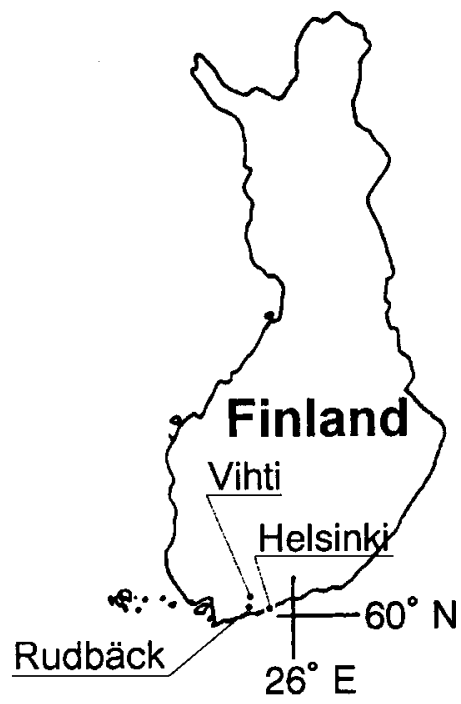

$200 \mathrm{~km}$
N

Moraines

Open Bedrock

Peatland

Groundwater Tubes

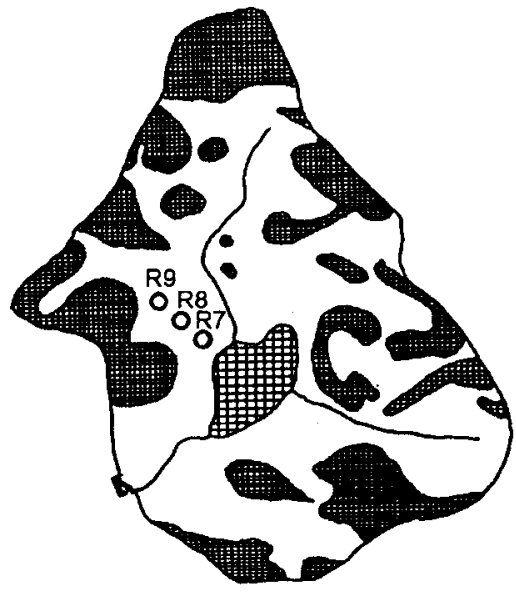

$200 \mathrm{~m}$

Fig. 1. Location of the Rudbäck catchment and the Vihti climate station, measurement sites and soil types of the catchment.

courses within the catchment. The results of the refractions together with a map of the exposed bedrock area were used to formulate an approximate model of mineral soil depth $\left(20 \times 20 \mathrm{~m}^{2}\right.$ resolution). The available soil maps were used to classify the distribution of soils as shown in Fig. 2.
The local climate is cold temperate and is characterised by rainfalls of relatively low intensity with a mean annual uncorrected precipitation of $700 \mathrm{~mm}$ (1992-96). About 15$25 \%$ of annual precipitation is snowfall, and snowmelt dominates the annual maximum runoff. A v-notch measure-

\section{Elevation}
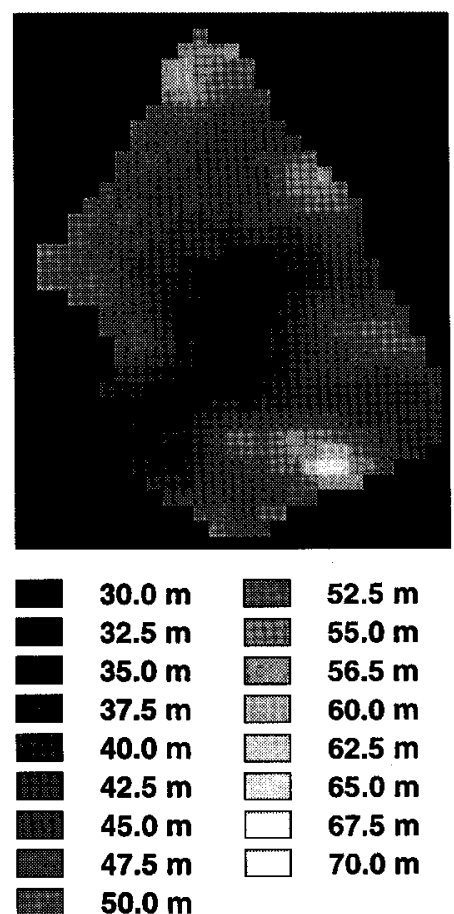

$30.0 \mathrm{~m}$ $32.5 \mathrm{~m}$ $35.0 \mathrm{~m}$ $37.5 \mathrm{~m}$ $40.0 \mathrm{~m}$ $42.5 \mathrm{~m}$ $45.0 \mathrm{~m}$ $47.5 \mathrm{~m}$ $50.0 \mathrm{~m}$
Soil Profile Depth
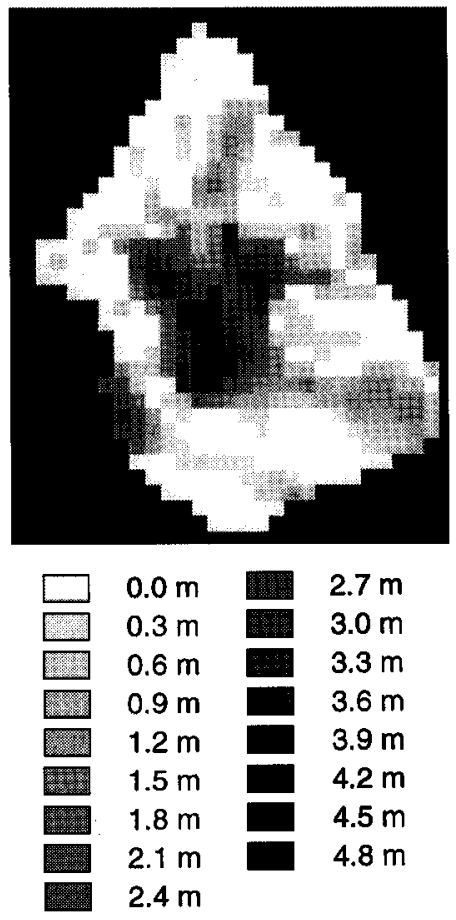

$0.0 \mathrm{~m}$ $0.3 \mathrm{~m}$ $0.6 \mathrm{~m}$ $0.9 \mathrm{~m}$ $1.2 \mathrm{~m}$ $1.5 \mathrm{~m}$ $1.8 \mathrm{~m}$ $2.1 \mathrm{~m}$ $2.4 \mathrm{~m}$

\section{Soil Type}

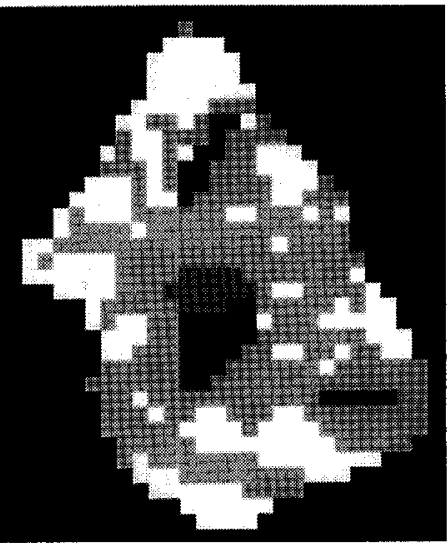

Outside Catchment

Bedrock

Moraine

Silty Clay

Peat

Fig. 2. $20 \times 20 \mathrm{~m}^{2}$ digital elevation model, soil depth model and soil types in the Rudbäck catchment. 

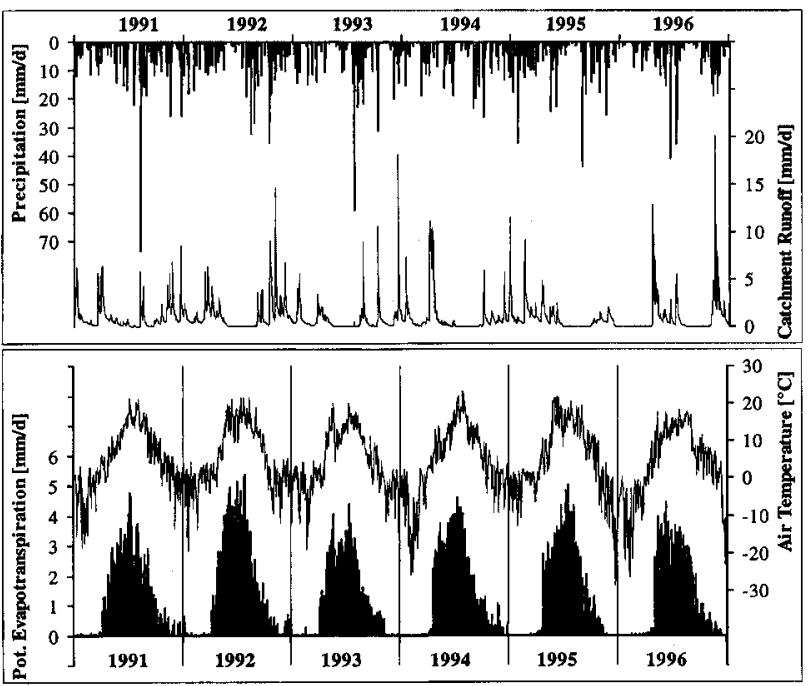

Fig. 3. Precipitation (uncorrected) and catchment runoff measured in Rudbäck, mean daily air temperature measured at the Vihti climate station, and an estimate of potential evapotranspiration during the period 1991-96.

ment weir has been installed at the outlet of a stream draining the catchment, and daily outflow values were available from the period 1991-96. Weekly measurements of water table depth were taken manually during the period 1991-94 at three points shown in Fig. 1. Meteorological measurements were available from a climate station about $30 \mathrm{~km}$ from Rudbäck in Vihti (daily values of maximum, minimum and average air temperature, wind speed, relative humidity and precipitation from 1996), $44 \mathrm{~km}$ from the site at the Helsinki-Vantaa Airport (global radiation), and $2 \mathrm{~km}$ from the site in Karuby (precipitation from 1992-95). Figure 3 presents precipitation and runoff in Rudbäck, mean daily air temperature in Vihti and an estimate of potential evapotranspiration.

\section{Methods}

The rainfall-runoff model was formulated over a finite horizontal grid $\left(20 \times 20 \mathrm{~m}^{2}\right)$, where the vertical soil moisture distribution was derived at each grid cell using an approximation to the one-dimensional Richards equation describing soil water movement. The basic time step was 1 day for the input data and the snow model, and 0.25 day for the soil water models. The time step decreased as a function of daily rainfall or snowmelt intensity.

\section{POTENTIAL EVAPOTRANSPIRATION}

The meteorological data were used to calculate an estimate of the daily potential evapotranspiration (Fig. 3) using the procedures suggested by Shuttleworth (1992). The estimate of potential evapotranspiration was based on the value derived for a reference crop, which was reduced by $20 \%$ because interception was not included in the potential value. In this study, the potential evapotranspiration was decreased further by $90 \%$ when the soil was covered with snow.

\section{SOIL WATER PROCEDURE IN THE UNSATURATED ZONE}

Total air volume in the soil pores, or the soil moisture deficit below a saturated moisture content, is given as an integral from the soil surface down to the water table:

$$
V_{a}=\int_{0}^{d_{g w}}\left(\theta_{s}-\theta\right) d z
$$

where $V_{a}$ is the total air volume in soil, $\theta$ is the volumetric soil water content, $\theta_{s}$ is the saturated soil water content, $d_{g w}$ is the depth to the water table, and $z$ is the vertical distance. If the soil water retention curve is known and a steady-state soil moisture distribution prevails such that the soil water potential above the water table varies linearly with depth, Eqn. (1) defines an explicit relationship between water table depth and moisture deficit in the soil profile. In this study, the soil water retention curve was modelled using an analytic van Genuchten function (van Genuchten, 1980). The assumption of a steady-state moisture profile above the water table has been used elsewhere in water balance studies . by Skaggs (1980), Skaggs et al. (1991), McCarthy et al. (1992) and Karvonen and Skaggs (1993).

In the approximation of the Richards equation, the air volume or soil moisture deficit $V_{a}$ is the basic state variable, which is influenced by water input to, and output from, the soil profile. The relationship between air volume and water table depth as defined in Eqn. (1) can be discretized in the form of a lookup table for each soil type with a different water retention curve. The assumption of a steady-state moisture distribution becomes invalid, for example, after

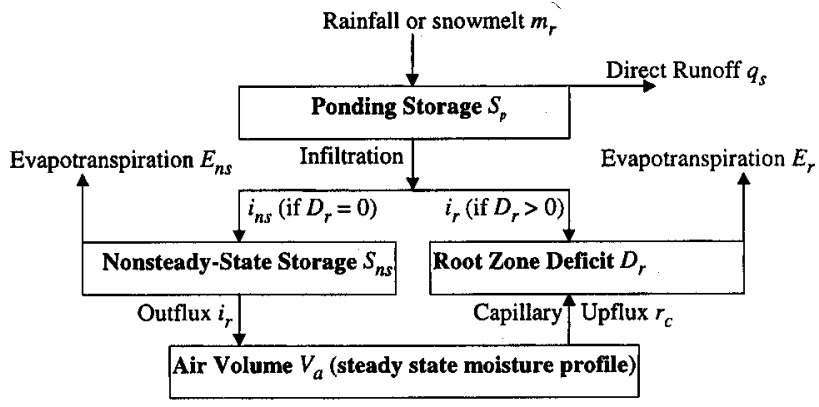

Fig. 4. Model for vertical pater movement in unsaturated soil. Nonsteady-state storage and root zone deficit act in parallel in that infiltration goes to the nonsteady-state storage only if the root zone deficit is zero, and evapotranspiration is extracted from the root zone only if the nonsteady-state storage is zero. 
infiltration in dry soil, and if the root zone experiences water deficit due to evapotranspiration. These two cases were considered here by introducing two additional state variables: nonsteady-state soil water storage and root zone moisture deficit.

The following continuity equations describe the water balance over a vertical soil profile:

$$
\begin{aligned}
\frac{d S_{p}}{d t} & =m_{r}-q_{d}-\left(i_{n s}+i_{r}\right) \\
\frac{d S_{n s}}{d t} & =i_{n s}-E_{n s}-i_{o u t}, \\
i_{n s} & =0 \text { if } D_{r}>0, \text { and } E_{n s}=0 \text { if } S_{n s}=0 \\
\frac{d D_{r}}{d t} & =E_{r}-i_{r}-r_{c} \\
i_{r} & =0 \text { if } D_{r}=0, \text { and } E_{r}=0 \text { if } S_{n s}>0 \\
\frac{d V_{a}}{d t} & =-i_{o u t}+r_{c}
\end{aligned}
$$

where $S_{p}$ is the soil surface water storage, $m_{r}$ is rainfall or snowmelt, $q_{d}$ is surface runoff, $i_{n s}$ is infiltration to increase the nonsteady-state storage, $i_{r}$ is infiltration to decrease the root zone deficit, $S_{n s}$ is the nonsteady-state soil water storage, $E_{n s}$ is evapotranspiration from the nonsteady-state storage, $i_{o u t}$ is the outflux from the nonsteady-state storage to the saturated soil, $D_{r}$ is the water deficit in the root zone, $E_{r}$ is evapotranspiration from the root zone, $r_{c}$ is the capillary upflux from the water table to the root zone, and $V_{a}$ is the volume of air in the soil profile under the prevailing steady-state distribution of vertical soil moisture. The interaction of the variables is illustrated in Fig. 4.

According to Eqn. (2), rainfall or snowmelt is an input to the soil surface storage, which has a maximum prescribed value. Water in excess of the maximum surface storage becomes saturation excess overland flow $q_{d}$, which represents the contribution of direct rainfall or snowmelt in runoff. Infiltration $\left(i_{n s}+i_{r}\right)$ is an output from the soil surface storage, and is described according to the boundary condition which states that the maximum infiltration capacity at the soil surface equals the total available soil moisture deficit. Infiltration is an input to the nonsteadystate storage or the root zone deficit as explained below.

If the water table is located deep in the profile, an infiltration event results in a nonsteady-state moisture distribution and a relatively long time may pass before the moisture distribution approaches steady-state. A state variable, $S_{n s}$, was introduced to store infiltrating water temporarily in the root zone (Eqn. 3). The maximum percolation from the nonsteady-state water storage down to the saturated soil was taken as:

$$
i_{\text {out }}=\bar{K}_{r}
$$

where $\bar{K}_{r}$ is an estimate of average hydraulic conductivity in the root zone. The maximum value of the nonsteady-state storage is restricted to the total air volume of the soil profile.

The other process resulting in a nonsteady-state soil moisture distribution is water extraction by evapotranspiration from the root zone (Eqn. 4). The root zone deficit, $D_{r}$, acts in parallel with the nonsteady-state storage, $S_{n s}$, in that infiltration, $i_{r}$, is directed to the root zone until the deficit is zero. Nonsteady-state storage is increased by infiltration, $i_{n s}$, only after the root zone deficit has been balanced. On the other hand, evapotranspiration, $E_{n s}$, is extracted at the maximum (potential) rate from nonsteady-state storage until $S_{n s}$ is emptied. Any further evapotranspiration, $E_{r}$, results in a root zone deficit. This ensures that the root zone deficit has a positive value only after the nonsteady-state water storage becomes zero. The root zone deficit reduces the root zone moisture content, which restricts the evapotranspiration, $E_{r}$, from its potential value according to a reduction factor which is a piece-wise linear function of the soil water potential in the root zone.

The root zone deficit is reduced by capillary upflux, $r_{c}$, from the saturated soil profile. The capillary upflux is derived as a steady-state solution to the one-dimensional Richards equation at a prescribed water table depth and assumed suction of $-50 \mathrm{~m}$ at the bottom of the root zone. A lookup table is formulated between discrete values of water table depth and the corresponding steady-state capillary upflux. The hydraulic conductivity for unsaturated soil is derived as a function of soil water potential as presented by Mualem (1976) and van Genuchten (1980).

Equation (5) shows the continuity equation for the moisture deficit or air volume in soil, $V_{a}$, corresponding to a steady-state soil moisture distribution. The outflux, $i_{\text {out }}$, from the nonsteady-state storage decreases the air volume, and the capillary upflux, $r_{c}$, which results from evapotranspiration from the root zone, increases the air volume. Equations (2-5) were solved using an explicit Euler solution, the time step of which varied from one day to a fraction of a day depending on the daily precipitation input.

The vertical soil moisture profile at any time can be calculated from the state variables using the van Genuchten function for soil water retention. The soil moisture is based on the steady-state distribution, which is modified in the root zone according to the state variables. Root zone soil moisture is increased if the nonsteady-state storage is positive and decreased if the root zone deficit has a positive value (Fig. 5).

\section{SOIL WATER MOVEMENT IN THE SATURATED ZONE}

The proposed approximation for the vertical soil moisture distribution was combined with a two-dimensional ground water model to formulate a quasi-three-dimensional rainfallrunoff model. The catchment was discretized horizontally using a finite two-dimensional grid, and a soil profile of a prescribed depth was attached to each grid cell. Horizontal 


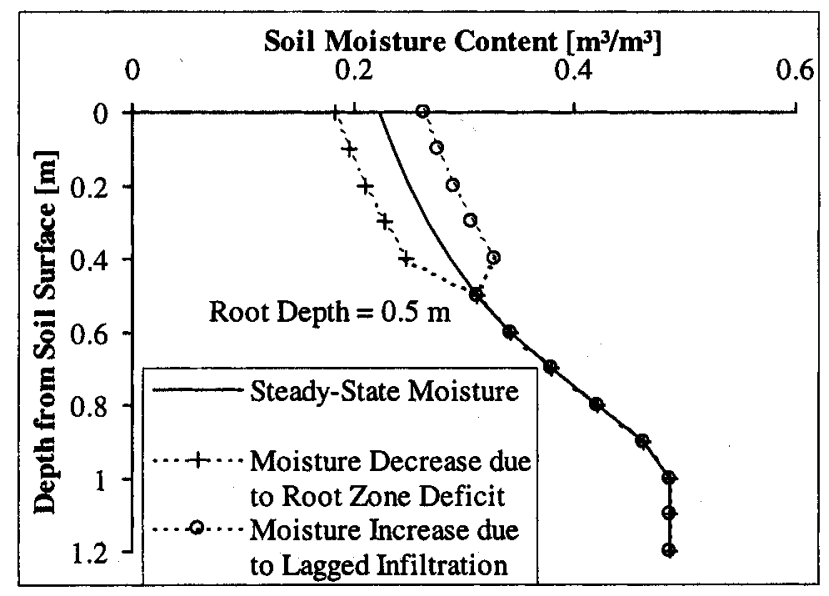

Fig. 5. An example of the estimated soil moisture distribution obtained using the steady-state profile modified by root zone water extraction or lagged infiltration.

water movement was assumed to take place in the saturated part of the soil and was described using a numerical solution to the continuity equation coupled with Darcy's law:

$$
s \frac{\partial h}{\partial t}=\frac{\partial}{\partial x}\left(T_{x} \frac{\partial h}{\partial x}\right)+\frac{\partial}{\partial y}\left(T_{y} \frac{\partial h}{\partial y}\right)
$$

where $h$ is the hydraulic head, $T$ is transmissivity, $s$ is the storage coefficient, $x$ and $y$ are the horizontal coordinates, and $t$ is time. An implicit solution to the ground water model was effected numerically over the finite grid using the iterative alternating direction method (IADI).

The combined model is quasi-three-dimensional in the sense that the water balance over a catchment during a time step is derived in two stages. Given the initial distribution of water table depth, the vertical water fluxes and the resulting change in the water table elevation at each grid cell are calculated in the first stage. The horizontal water movement in the saturated soil and the resulting change in the water table elevation over the grid are calculated in the second stage. The depth to the water table (at any grid cell), $d_{g m}$, defines the initial hydraulic head, $h$, at the start of the second stage calculation:

$$
h=z_{0}-d_{g w}
$$

where $z_{0}$ is the elevation of the soil surface. The coupling of the models is illustrated in Fig. 6.

The transmissivity for each grid cell was calculated using an exponential function similar to the one used in TOPMODEL (Beven and Kirkby, 1979):

$$
T=\int_{d_{g w}}^{z_{B O T}} K_{s} e^{-f z} d z
$$

where $K_{s}$ is the saturated hydraulic conductivity at the soil surface, $z_{B O T}$ is the depth to the impermeable bottom, and $f$

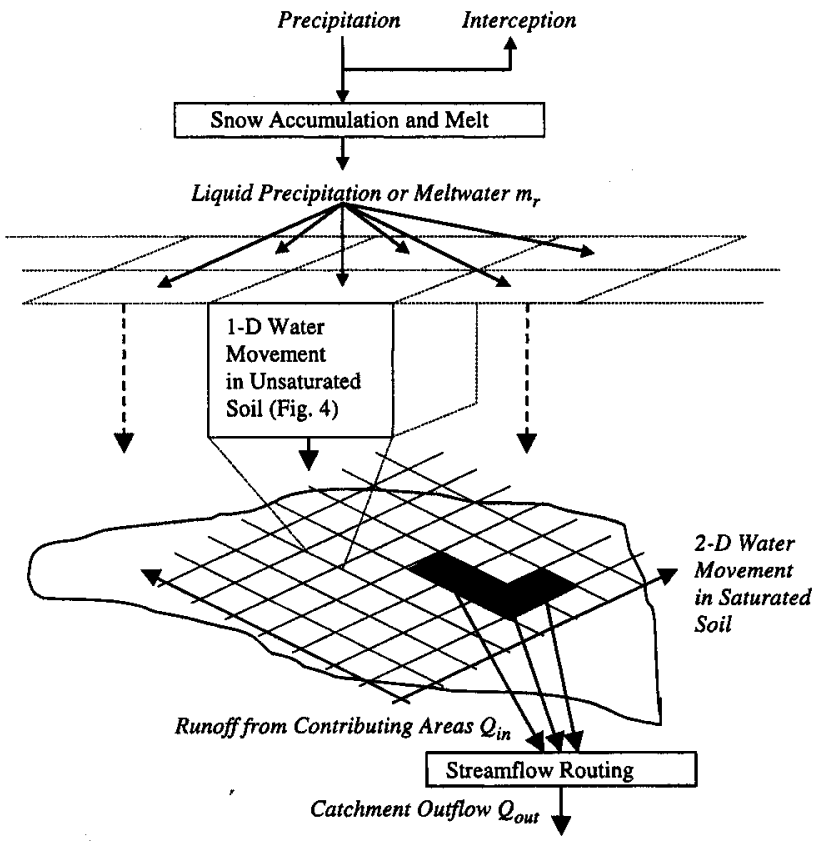

Fig. 6. Representation of the quasi-three-dimensional rainfall-runoff model. The proposed approximation of the Richards equation was used to evaluate soil water movement in the unsaturated soil zone. Direct rainfall/snowmelt or soil water exfiltration generates runoff over saturated grid cells. Runoff from bedrock areas is redistributed over soilcovered areas.

is the shape parameter. The transmissivity between two grid cells was calculated as a harmonic average and the transmissivity at the catchment boundary was set to zero to represent a water divide.

The storage coefficient $s$ was calculated according to its definition:

$$
s=-\frac{\Delta V_{a}}{\Delta h}=\frac{\int_{d_{g w}}^{d_{g w}+\Delta d_{g w}}\left(\theta_{s}-\theta\right) d z}{\Delta d_{g w}}
$$

where $V_{a}$ is the total volume of air, and $h$ is the hydraulic head. The saturated soil profile is treated as an unconfined aquifer and the storage coefficient can be calculated directly using Eqns. (1) and (10). The change in the total volume of air divided by the corresponding change in water table depth gives the storage coefficient. The storage coefficient is calculated inside the iteration loop to provide accurate estimates.

If the calculated water table at any grid cell was above the soil surface, a corresponding amount of exfiltration was added to the soil surface water storage. For example, the soil surface storage $S_{p}$ at a saturated grid cell was updated:

$$
\frac{d S_{p}}{d t}=s\left(h-z_{0}\right)-q_{s}
$$

where $q_{s}$ is runoff generated by exfiltration. Runoff $q_{s}$ was 
produced only if the surface storage exceeded the prescribed maximum value. $q_{s}$ represented the contribution of soil water flow to catchment runoff.

\section{FLOW ROUTING}

Runoff was not routed over the hillslopes, except that runoff generated on areas of exposed bedrock was redistributed over the soil-covered area. The runoff generated over the soil-covered saturated profiles formed a direct input to a nonlinear reservoir, which acted as a simple routing scheme for the channel flow:

$$
\begin{aligned}
& \frac{d S_{c h}}{d t}=Q_{i n}-Q_{o u t} \\
& Q_{i n}=\sum\left(q_{d}+q_{s}\right) \\
& Q_{o u t}=k_{c h} S_{c h}^{n}
\end{aligned}
$$

where $S_{c h}$ is the storage representing water in the stream channel, $Q_{i n}$ is the sum of runoffs generated over the grid cells (Fig. 6), $Q_{\text {out }}$ is the catchment outflow, $k_{c h}$ is the discharge coefficient, and $n$ is the exponent. An implicit solution was used for the reservoir equation.

\section{SNOWMELT AND INTERCEPTION}

A snowmelt procedure was added to the model to enable calculation of the annual water balance. A degree-day model was used to describe snow processes, which were calculated separately over the exposed bedrock and the soil-covered areas. The interaction between the water equivalent of snow and liquid water held in snow was calculated from the estimates of snowmelt and refreezing:

$$
\begin{aligned}
& M=m_{f}\left(T_{a}-T_{0}\right), T_{a}>T_{0} \\
& F=f_{f}\left(T_{0}-T_{a}\right), T_{a}<T_{0}
\end{aligned}
$$

where $M$ is snowmelt, $F$ is the rate of refreezing, $T_{a}$ is the air temperature, $T_{0}$ is the base temperature, $m_{f}$ is the degreeday melt factor, and $f_{f}$ is the refreezing factor $(0.05 \mathrm{~mm} /$ $\left.{ }^{\circ} \mathrm{C} / \mathrm{d}\right)$. The melt factor was reduced by $70 \%$ during early January and the reduction decreased linearly with time to $0 \%$ by the end of March. Melt water was held in snow until the prescribed water holding capacity of snow $(10 \%)$ was filled.

Canopy processes affecting snow distribution and melt were largely ignored, except that interception in trees was simply assumed to be a constant fraction of precipitation. The maximum interception capacity was set to a prescribed value, which was higher for snowfall than for rainfall. Interception over exposed bedrock areas was set to zero.

\section{Model testing and application in Rudbäck}

\author{
TESTING OF THE SOIL MOISTURE ROUTINE
}

The performance of the conceptual approximation of the unsaturated soil water processes was compared to that of the one-dimensional Richards equation, which was solved numerically using a finite difference scheme (e.g. Karvonen, 1988).

The two models were used to simulate the vertical soil moisture distribution in a column of homogeneous soil, the properties of which were defined according to the measurements available from the Rudbäck catchment. Measured soil water characteristic curves representing the illuvial layer of podzolic forest soil were used for the soil column calculations. The measured saturated hydraulic conductivity varied over a wide range $(0.04-3.9 \mathrm{~m} / \mathrm{d})$ in the surface layer down to a depth of $0.8 \mathrm{~m}$ (Lepistö and Kivinen, 1997). A saturated hydraulic conductivity of $0.5 \mathrm{md}^{-1}$ was used in the comparison. Van Genuchten functions were used to model the soil water characteristics (see Fig. 7). The root depth was taken as $0.5 \mathrm{~m}$ and the total profile depth was $2.0 \mathrm{~m}$.

The two models were compared during snow-free conditions from early May until the end of November, 1995 and 1996. The initial ground water table depth was set so that the water table remained below the soil surface until the end of the calculation period. The comparison was not performed for the saturated conditions, because the boundary conditions of the models at the soil surface were different. The potential evapotranspiration was given as an input as described earlier.

Generally the approximation compared well with the results of the Richards equation for water table depth and for individual time series of soil moisture (Fig. 8). The greatest discrepancy between the simulated values of soil

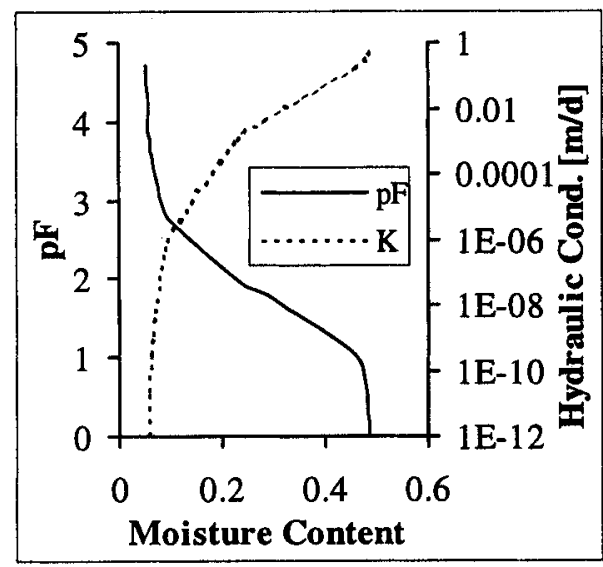

Fig. 7. Van Genuchten functions of mater retention ( $p F)$ and unsaturated hydraulic conductivity (K) fitted for moraine Rudbäck soil. The functions were used in testing soil water models. 

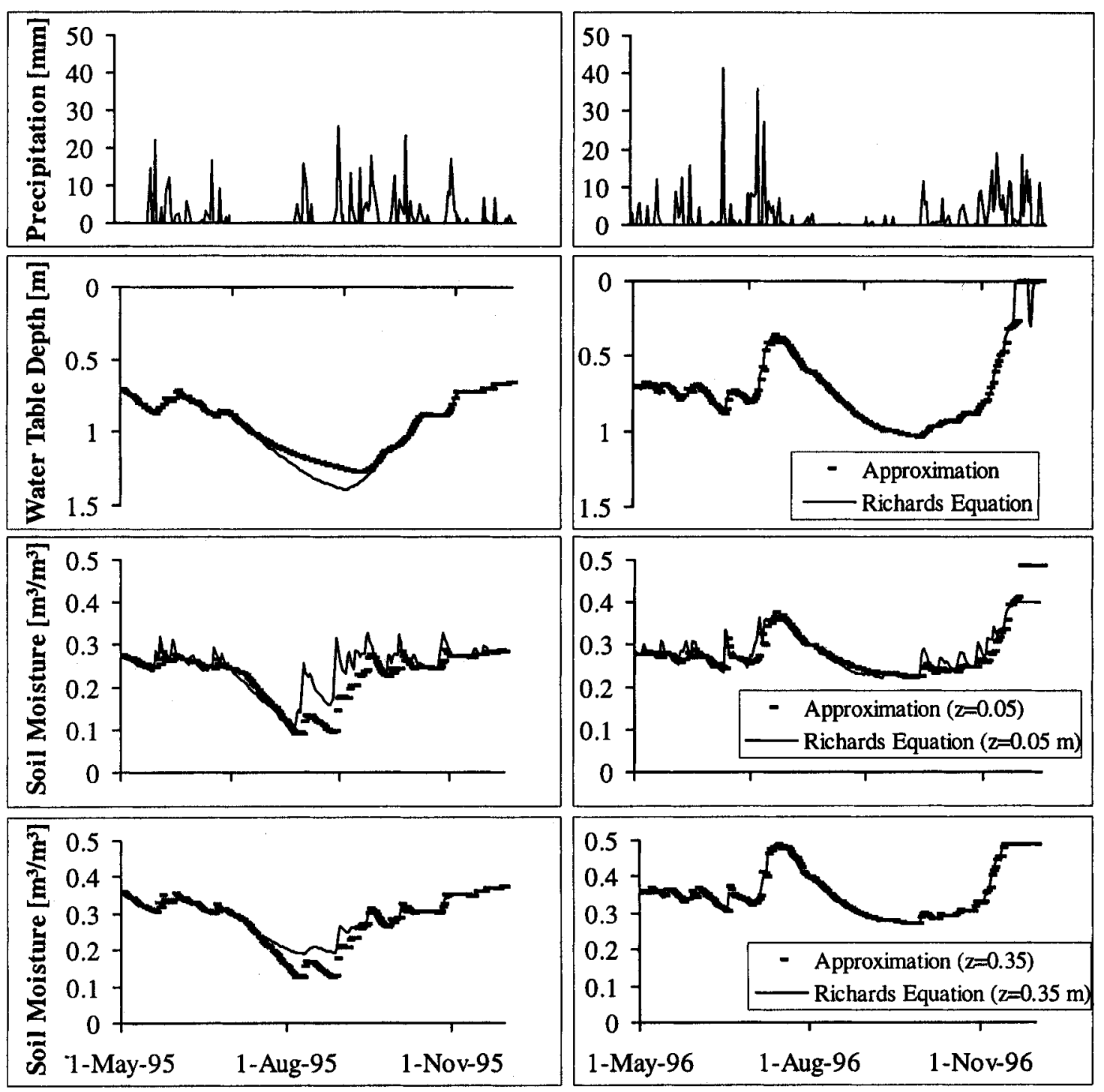

Fig. 8. Calculated mater table depth and soil moisture time series at the depths of 0.05 and $0.35 \mathrm{~m}$ during May-November 1995 and 1996. Results using the numerical solution to the one-dimensional Richards equation and the proposed approximation are presented.

moisture was found near the soil surface when infiltration occurred after a prolonged dry period. The closer the water table remained to the soil surface, the better was the agreement between the approximation and the numerical solution of the Richards Equation. The approximation is most valid during time periods when most of the runoff is generated and the water table is close to the soil surface (about $0-1 \mathrm{~m}$ ). The approximation becomes less appropriate during dry periods when only minor amounts of runoff are produced.

\section{MODEL APPLICATION IN RUDBÄCK}

\section{Model parameters}

The Rudbäck catchment was parameterised using a grid, the resolution of which $\left(20 \times 20 \mathrm{~m}^{2}\right)$ corresponded to the estimated digital models of elevation, soil depth and soil type (Fig. 2). The soil water characteristic curves for moraine soil were based on laboratory measurements, but the characteristic curves for the small areas of silty clay and peat were taken from the literature (e.g. Driessen, 1986). The curves are presented in Fig. 9.

Vegetation, root zone depth $(0.7 \mathrm{~m})$ and interception fraction $(40 \%)$ were assumed homogeneous over the forest soil grid cells. Near the tops of the hills, no interception was assumed and the root zone was as deep as the thin profile of mineral soil. The maximum interception was set to $0.0012 \mathrm{~m}$ for rainfall and to $0.01 \mathrm{~m}$ for snowfall events. The correction factors were 1.33 and 1.05 for snowfall and rainfall, respectively. The boundary conditions were a noflow boundary at the catchment divide and a maximum 

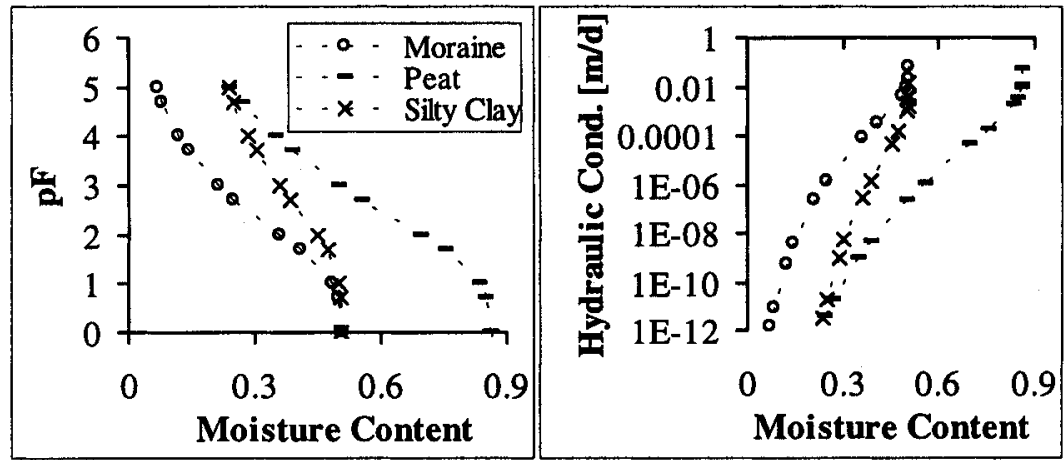

Fig. 9. Soil water retention curves used in the modelling application.

water table elevation which equalled the soil surface elevation at saturated nodes.

The parameters that were not systematically calibrated were taken as best estimates. Because the air temperature was measured $30 \mathrm{~km}$ north of the catchment under slightly colder conditions, the temperature limits for precipitation form (snow - wet snow - rain) were taken as a range between -1.5 and $0.5^{\circ} \mathrm{C}$. The relative amount of rain or snowfall varied linearly between the limits. The potential evapotranspiration was reduced by $90 \%$ if the ground was covered with snow in order to account for the effect of low soil temperature on evapotranspiration. This potential value was allowed to vary $\pm 10 \%$ in the calibration. Table 1 lists the parameters that were calibrated systematically using the optimisation algorithm given by O'Neill (1971).

\section{Model results}

Daily runoff during six years, 1991-96, was calculated to assess the performance of the model. The model was calibrated using the catchment runoff data of 1991-93 and tested using the data of 1994-96. The initial values for water table elevation, soil surface storage and nonsteady-state soil moisture storage at each grid cell were calculated from the last day of 1993. Table 1 shows the values of the calibrated parameters. The results were assessed in terms of the explained variance coefficient $R_{v}$, the determination coefficient $R_{d}$, and the correlation coefficient $R_{c}$ (e.g. Franchini $e t$ al., 1996):

$$
\begin{aligned}
& \boldsymbol{R}_{v}=1-\frac{\sum_{i}\left(\epsilon_{i}-\mu_{\epsilon}\right)^{2}}{\sum_{i}\left(Q_{i}^{r}-\mu_{r}\right)^{2}} \\
& \boldsymbol{R}_{d}=1-\frac{\sum_{i}\left(\epsilon_{i}\right)^{2}}{\sum_{i}\left(Q_{i}^{r}-\mu_{r}\right)^{2}} \\
& \boldsymbol{R}_{c}=\left(R_{d}\right)^{1 / 2}
\end{aligned}
$$

where $\epsilon_{i}=Q_{i}^{r}-Q_{i}^{s}$ (error), $Q^{r}$ is the measured series of runoff, $Q^{s}$ is the simulated runoff, $\mu_{\varepsilon}$ is the mean of errors, and $\mu_{r}$ is the mean of measured runoff.

The coefficient of determination was 0.72 for the calibration period and 0.68 for the test period. Table 2 shows the calculated annual mass balance and the fitness coefficients. The results of the calibration showed that spring snowmelt periods were simulated well, but that the highest runoff peaks induced by autumn rainfalls were underestimated (Fig. 10). For example, the model calculated negligible runoff during the first measured runoff events after the summer of 1992. The results of the testing were similar to the results of the calibration except for the year 1995. The highest runoff peaks were underestimated during early winter 1995, but the later spring melt was overestimated. Overall, the timing of the calculated spring snowmelt was successful when compared with measurements. The estimate of evapotranspiration was realistic during the summer when minor stream flows were measured. The annual cumulative runoff was in accordance with measurements during years other than 1991 and 1995. Autumn base flow was overpredicted during 1991 and spring snowmelt was higher than measured during 1995 , as shown in Table 2.

Table 1. Calibrated model parameters for 1991-93 data from the Rudbäck catchment.

Parameter

Value

Degree-day factor $m_{f}\left[\mathrm{~mm} / \mathrm{d} /{ }^{\circ} \mathrm{C}\right]$

1.5

Base temperature $T_{0}\left[{ }^{\circ} \mathrm{C}\right]$

$-0.57$

Initial SWE [m]

Maximum soil surface storage [m]

0.030

Lateral hydraulic conductivity of saturated soil

0.01 $K_{\text {sat }}[\mathrm{m} / \mathrm{d}]$

Shape parameter $f$ (affects decrease of $K_{\text {sat }}$ with $\quad 0.8$ depth)

Routing retention coefficient $k_{c h}[1 / \mathrm{d}]$

Exponent in routing equation $n$

2.0

Initial routing storage $[\mathrm{m}]$

Restriction coefficient for potential 0.0086 evapotranspiration 
Table 2. Cumulative runoff, fitness coefficients between measured and calculated runoff, and cumulative water balance components during 1991-96.

\begin{tabular}{llllllll}
\hline & 1991 & 1992 & 1993 & 1994 & 1995 & 1996 & Total \\
\hline Coeff. of determination & 0.73 & 0.82 & 0.59 & 0.81 & 0.34 & 0.67 & 0.69 \\
Correlation coeff. & 0.85 & 0.90 & 0.77 & 0.90 & 0.58 & 0.82 & 0.83 \\
Explained variance coeff. & 0.75 & 0.82 & 0.59 & 0.81 & 0.39 & 0.67 & 0.70 \\
Measured catchment runoff [mm] & 377 & 415 & 273 & 339 & 291 & 321 & 2016 \\
Calculated catchment runoff [mm] & 441 & 420 & 261 & 347 & 386 & 326 & 2181 \\
Direct runoff [mm] & 288 & 262 & 160 & 241 & 230 & 239 & 1420 \\
Precipitation [mm] & 864 & 830 & 677 & 735 & 798 & 705 & 4609 \\
Interception [mm] & 95 & 111 & 90 & 90 & 111 & 95 & 592 \\
Rain/snowmelt [mm] & 794 & 724 & 540 & 684 & 647 & 643 & 4032 \\
Evapotranspiration [mm] & 346 & 318 & 275 & 310 & 302 & 309 & 1860 \\
Runoff to channels [mm] & 441 & 416 & 262 & 362 & 368 & 327 & 2176 \\
Soil water storage change [mm] & 7 & -10 & 3 & 13 & -23 & 7 & -3 \\
Soil water balance error [mm] & 0 & 0 & 0 & -1 & 0 & 0 & -1 \\
\hline
\end{tabular}

Depth to the groundwater table was measured at three locations in the catchment. The modelled results of the water table depth were compared to the measurements at the grid cells closest to the groundwater tubes. The calculated water table depth was sensitive to the surface topography, which was checked to match with the measured elevation given by the manual levelling. Figure 11 shows the comparison which indicates that the calculated water table depth was in accordance with the measurements at the lowest elevation (tube R7, Fig. 1). At the higher elevations
(R8-R9), the rapid fluctuation of water table was not quite replicated but overall the results were reasonable.

The calculated snow water equivalent followed the dynamics of the measurements reported from the basin of the river Vantaanjoki about $40 \mathrm{~km}$ east of the site but the actual magnitudes were not comparable due to different local precipitation conditions (Fig. 12).

Table 3 shows the separation of monthly runoff to contributions from direct rainfall/snowmelt and soil water exfiltration during 1991-92. The total fraction of direct

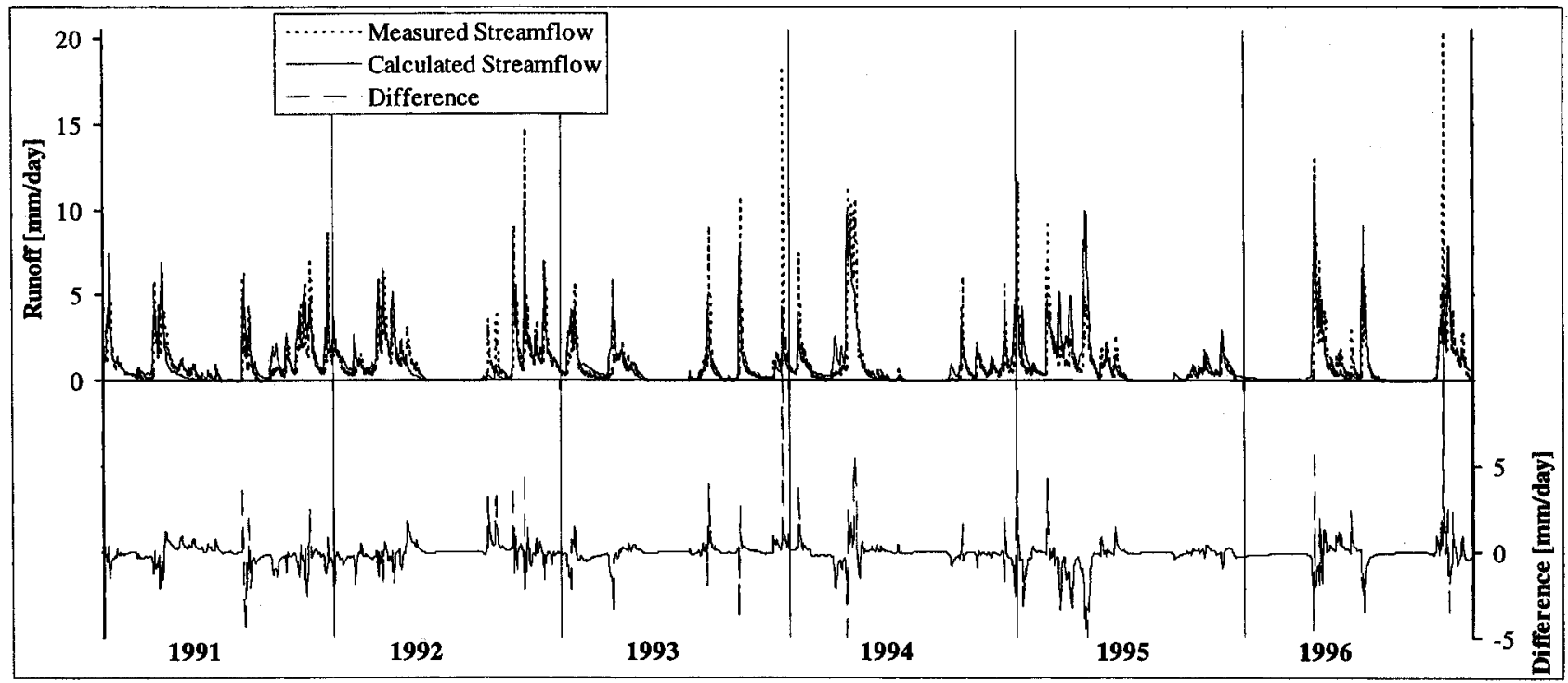

Fig. 10. Measured and calculated catchment runoff and their difference during 1991-96. 1991-93 was the calibration period and 1994-96 was used for model testing. 

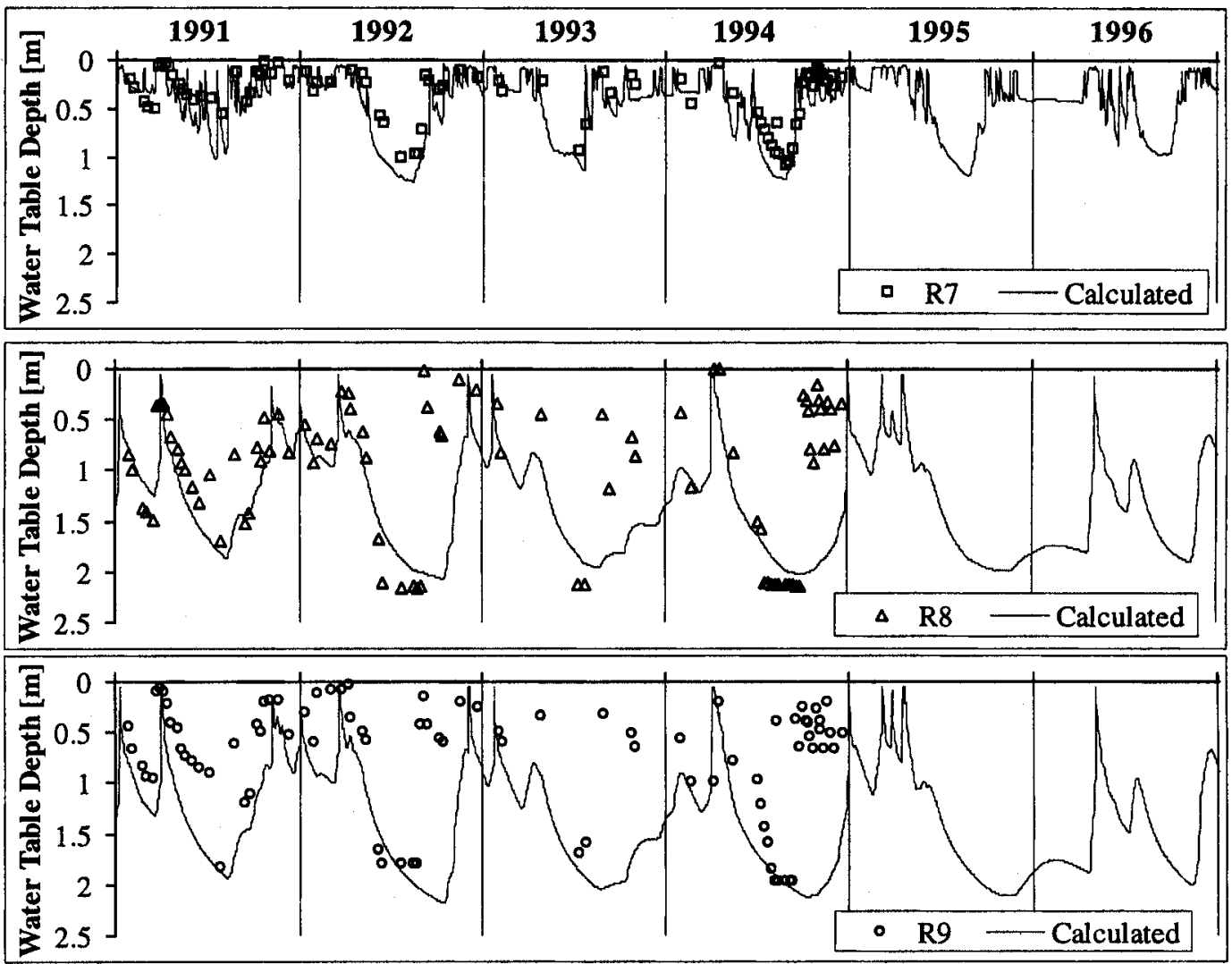

Fig. 11. Measured and calculated depth to water table at the observation points $(R 7-R 9)$ and at the closest grid cells during 1991-96. No measurements were available for the years 1995-96.

runoff was up to $63-65 \%$ and decreased during the wet season when exfiltration dominated the runoff generation. The fraction of direct runoff was notably high during the summer months. Table 3 also shows the average monthly fractions of event water according to the analysis of oxygen isotope concentrations in precipitation, streamwater and groundwater (Lepistö, 1994). Event water was traced to direct rainfall or snowmelt generating saturated overland flow and some shallow groundwater flow with a very short transit time. Pre-event water was older water from catchment soils.

Figure 13 presents the percentage of runoff-contributing areas from the total catchment area during 1991-92. The contributing areas characterised the grid cells where the soil surface storage was filled up and where exfiltration or direct rainfall and/or snowmelt had generated runoff. Exposed

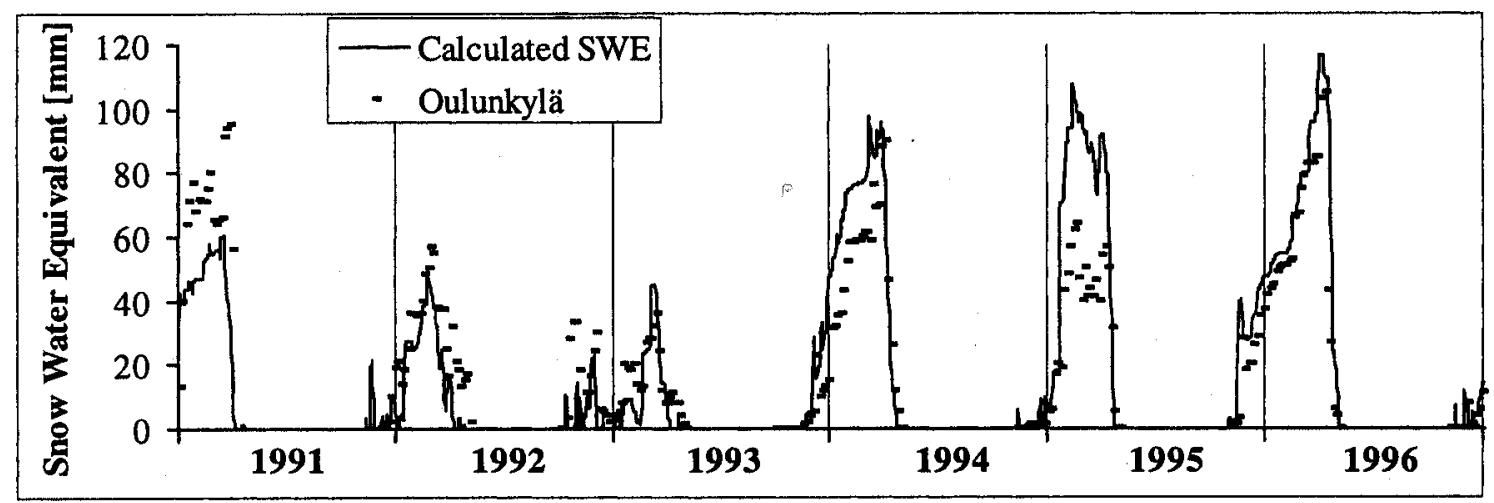

Fig. 12. Calculated average snom water equivalent over the catchment and measured snow water equivalent 40 km east of the catchment during $1991-96$. 
Table 3. Calculated monthly fractions of direct rainfall/ snowmelt from total runoff. Measured fractions of event water are taken from Lepistö (1994).

\begin{tabular}{llllll}
\hline & \multicolumn{2}{c}{$\begin{array}{c}\text { Calculated } \\
\text { fraction of direct } \\
\text { runoff [\%] }\end{array}$} & & \multicolumn{2}{c}{$\begin{array}{c}\text { Fraction of event } \\
\text { water from the } \\
\text { tracer analysis [\%] }\end{array}$} \\
\cline { 2 - 3 } \cline { 5 - 6 } & 1991 & 1992 & & 1991 & 1992 \\
\hline January & 60 & 41 & & 13 & 13 \\
February & 23 & 42 & 3 & 14 \\
March & 70 & 65 & 33 & 9 \\
April & 58 & 61 & 3 & 4 \\
May & 44 & 25 & 3 & 1 \\
June & 66 & 28 & & 1 & 0 \\
July & 92 & 0 & 10 & 0 \\
August & 91 & 98 & 66 & 12 \\
September & 72 & 92 & 26 & 13 \\
October & 52 & 86 & 27 & 8 \\
November & 67 & 65 & 24 & 15 \\
December & 59 & 58 & 14 & 14 \\
Total & 65 & 63 & 21 & 10 \\
\hline
\end{tabular}

bedrock areas were not considered as contributing areas, because runoff from such grid cells was redistributed over the forest grid cells. The extent of the modelled contributing areas reached a minimum in summer $(0-1 \%)$ and a maximum during the wet season (30-40\%). Figure 13 also shows the percentage of contributing areas of the event water estimated by dividing the amount of event water by the total monthly rainfall and/or snowmelt (Lepistö, 1994). The extent of the contributing areas from the different methods could not be compared directly, but the seasonal dynamics of the series were similar.

\section{Discussion}

The results of simulated runoff and water table dynamics in Rudbäck were acceptable but not excellent in terms of goodness of fit between the measured and calculated runoff. The model results were sensitive to soil parameters such as hydraulic conductivity and mineral soil depth. Inclusion of the spatial variability of mineral soil depth in the model parameterisation improved the results although the digital soil depth model was only an approximation.

The data quality of the measured catchment runoff caused some concern because water freezing during the winter and spring snowmelt may, in some cases, affect the operation of the measurement weir. The largest errors in the annual water balance occurred in 1995 when the total calculated runoff was $33 \%$ higher than measured. During the same year, the total runoff at a weir which was located $1.5 \mathrm{~km}$ downstream and which drained an area of $1.42 \mathrm{~km}^{2}$ was $42 \%$ higher compared with the study catchment. Precipitation during 1996 and air temperature during 1991 96 were measured $30 \mathrm{~km}$ north of the site on the other side of the Salpausselkä ridge. The meteorological observations in Vihti may not represent the study site well enough to support the snowmelt and evaporation calculations. The available meteorological data were daily averages, which were used as such to run the model. For example, the exact time of precipitation was not known and the precipitation intensity was assumed to be uniform during one day. Since the measured runoff series showed a rapid response to rainfalls, the use of hourly data would probably have improved the model results in terms of fit to the measured runoff.

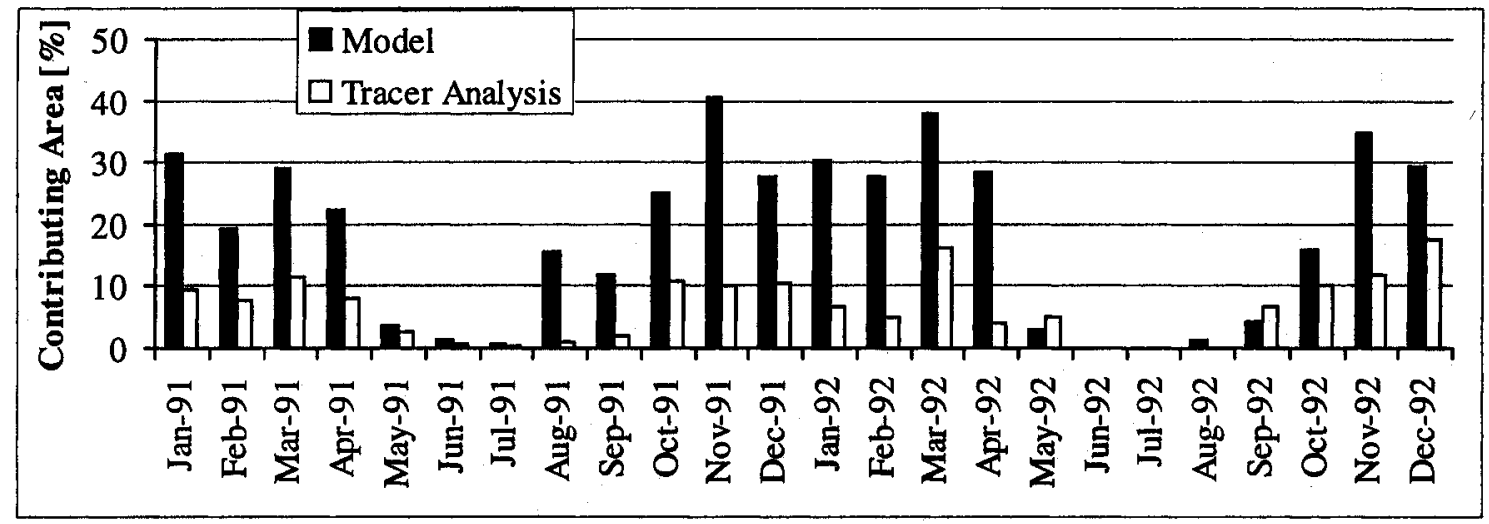

Fig. 13. The extent of runoff-contributing areas by the model and the extent of event mater-contributing areas by the tracer analysis from Lepistö (1994). The modelled values represented the average percentage of the total catchment area that generates runoff. Exposed bedrock areas were not considered as contributing areas. The estimates from the tracer analysis include areas discharging only 'new' water from recent rainfall and/or meltwater (Lepistö, 1994). 
Lepistö and Kivinen (1997) used TOPMODEL to predict catchment response during 1991-94. Their results were realistic, because checks for annual cumulative runoff and water table dynamics were successful. Problems were encountered in replicating the peak flows in the same way as in this study. On the other hand, Lepistö and Kivinen (1997) found summer flows, overpredicted compared to the measured negligible flows. The annual runoff dynamics were replicated better using the present model, and the annual water balance was similar to the results of Lepistö and Kivinen (1997). For example, the water balance error during $1991-94$ was $5 \%$ in this study and $3 \%$ in the TOPMODEL application. Lepistö and Kivinen (1997) compared the calculated average depth to water table with the point measurements, but the present study allowed a more detailed comparison at the measurement locations. The water table calculated by the quasi-three-dimensional model was closer to the soil surface and compared better with the measurements than the average water table depth computed by TOPMODEL.

Lepistö (1994) pointed out a negative correlation between water table depth and measured catchment runoff, which suggested that runoff generation was related to the dynamics of saturated areas as assumed in the present study. Lepistö (1994) studied the origin of runoff water using estimated monthly variation of oxygen isotope concentration in precipitation, streamflow and groundwater. The results suggested that $10-20 \%$ of annual runoff originated from event water and $80-90 \%$ originated from pre-event water in catchment soils. However, the fraction of event water may be considerably higher in the rainfall event time-scale, up to $50-70 \%$ of the total runoff, and is related to the volume of rainfall (Lepistö et al., 1994). The calculations of the present study suggested that only 35$37 \%$ of annual runoff during 1991-92 was produced by exfiltration of water present in soil prior to the rainfall event. The isotopically traced runoff fractions are not directly comparable with the fractions calculated in this study, because runoff residence times and flow paths toward streams were not modelled explicitly. Despite these deficiencies, an approximate comparison can be made if the calculated runoff generated by the soil water exfiltration is assumed to represent the contribution of groundwater in runoff.

On the basis of hydrograph separation, Lepistö (1994) further estimated the fraction of event water-contributing areas within the catchment, which varied from $0 \%$ in July to $16 \%$ in November, 1991. The modelled percentages of saturated contributing areas were $1 \%$ and $41 \%$, respectively, and showed seasonal dynamics similar to earlier results as shown in Fig. 13.

In conclusion, the results obtained by modelling and by measurements using environmental isotopes as tracers call for future work on improved incorporation of tracer study results in physically based rainfall-runoff modelling.

\section{Summary}

A method was outlined to approximate the Richards equation in calculating one-dimensional water movement in an unsaturated soil profile. The approximation utilised the soil water retention curve to derive the vertical soil moisture profile as a steady-state distribution, which is altered in the root zone during drying or wetting of the soil. Comparison of the approximation with the one-dimensional solution of the Richards equation showed that the method applies during conditions when the water table remains relatively close to the soil surface. The approximation becomes less valid during prolonged dry periods.

The case study of a small forested catchment showed that the approximation can be linked easily. with a twodimensional numerical ground water model. The resulting quasi-three-dimensional system can be used to model soil moisture and runoff generation over a catchment. The model characterises grid-scale spatial variability of the soil properties and provides estimates of the vertical and horizontal soil moisture distribution. The model describes the dynamics of saturated contributing areas and runoff as a result of soil water exfiltration and direct rainfall/snowmelt. The case study showed that the model yielded acceptable results in terms of measured runoff and water table dynamics. A comparison with earlier results from environmental tracer studies showed that the modelled fraction of direct rainfall and snowmelt in streamflow and the modelled extent of saturated contributing areas were overestimated, even though the seasonal dynamics of the variables were similar to the results of the tracer analysis.

\section{Acknowledgements}

The authors thank Prof. Pertti Vakkilainen and Mr. Mikko Jauhiainen from the Helsinki University of Technology for discussions about forest hydrology. The first author acknowledges funding from the Academy of Finland and from the association of Maa- ja vesitekniikan tuki ry.

\section{References}

Abbott, M.B., Bathurst, J.C., Cunge, J.A., O'Connell P.E. and Rasmussen, J., 1986. An introduction to the European Hydrological System - Système Hydrologique Européen, "SHE", 1: History and philosophy of a physically-based, distributed modelling system, 7. Hydrol., 87, 45-59.

Bergström, S. and Graham, L.P., 1998. On the scale problem in hydrological modelling. F. Hydrol., 211, 253-265.

Bergström, S. and Forsman, A., 1973. Development of conceptual deterministic rainfall-runoff model, Nordic Hydrol., 4, 47-70.

Beven, K., 1989. Changing ideas in hydrology - the case of physically-based models, $\mathcal{F}$. Hydrol., 105, 157-172.

Beven, K. and Germann, P., 1982. Macropores and water flow in soils, Wat. Resour. Res., 18, 1311-1325.

Beven, K.J. and Kirkby, M.J., 1979. A physically based, variable contributing area model of basin hydrology, Hydrol. Sci. Bull., 24, 43-69.

Beven, K. and Wood, E.F., 1983. Catchment geomorphology and 
the dynamics of runoff contributing areas, $7 . H y d r o l$, , 65, 139158.

Beven, K., Calver, A. and Morris, E.M., 1987. The Institute of Hydrology Distributed Model (IHDM). Institute of Hydrology Report 97, Wallingford, UK.

Beven, K.J., Lamb, R., Quinn, P.F., Romanowicz, R. and Freer, J., 1994. TOPMODEL, In: Computer Models of Watershed Hydrology, Singh, V.P. (ed), Water Resources Publications, Littleton, Colorado, $1144 \mathrm{p}$.

Bonell, M., 1993. Progress in the understanding of runoff generation dynamics in forests, 7 . Hydrol., 150, 217-275.

Driessen, P.M., 1986. The water balance of a soil, In: Modelling of agricultural production: weather, soils and crops, van Keulen, $\mathrm{H}$. and Wolf, J. (eds), Simulation Monographs, Pudoc, Wageningen, 76-116.

Dunne, T. and Black, R.D., 1970. Partial area contributions to storm runoff in a small New England watershed, Wat. Resour. Res., 6, 1296-1311.

Dunne, T., 1983. Relation of field studies and modelling in the prediction of storm runoff, $\mathcal{7}$. Hydrol., 65, 25-48.

Franchini, M., Wendling, J., Obled, C. and Todini, E., 1996. Physical interpretation and sensitivity analysis of the TOPMODEL, 7. Hydrol., 175, 293-338.

Grayson, R.B., Moore, I.D. and McMahon, T.A., 1992. Physically based hydrologic modeling. 2 . Is the concept realistic? Wat. Resour. Res., 26, 2659-2666.

Horton, R.E., 1933. The role of infiltration in the hydrologic cycle, Transactions, American Geophysical Union, 14, 446-460.

Karvonen, T., 1988. A model for predicting the effect of drainage on soil moisture, soil temperature and crop yield, Helsinki University of Technology, Publications of the Laboratory of Hydrology and Water Resources Engineering, 1/1988, 215 p.

Karvonen, T. and Skaggs, R.W., 1993. Comparison of different methods for computing drainage water quantity and quality, Workshop on Subsurface Drainage Simulation Models, ICIDCIID 15th Congress, Hague, 201-216.

Karvonen, T., Koivusalo, H., Jauhiainen, M., Palko, J. and Weppling, K., 1999. A hydrological model for predicting runoff from different land use areas, 7 . Hydrol., 217, 253-265.

Kirkby, M.J., 1985. Hillslope hydrology, In: Hydrological Forecasting, Anderson, M.G. and Burt, T.P. (eds.), Wiley, Chichester, UK, 37-75.

Kirkby, M., 1988. Hillslope runoff processes and models, 7 . Hydrol., 100, 315-339.

Koivusalo, H., Paasonen-Kivekäs, M., Karvonen, T. and Vakkilainen, P., 1999. Water and nitrogen balance on a cultivated field: a characteristic hillslope approach, In: Impact of Land-Use Change on Nutrient Loads from Diffuse Sources, Heathwaite, L. (ed), IAHS publication no. 257, 157-162.

Lepistö, A., 1994. Areas contributing to generation of runoff and nitrate leaching as estimated by empirical isotope methods and TOPMODEL, Aqua Fennica, 24, 103-120.

Lepistö, A., 1996. Hydrological Processes Contributing to Nitrogen Leaching from Forested Catchments in Nordic Conditions, Monographs of the Boreal Environment Research No. 1, 72 p.

Lepistö, A. and Kivinen, Y., 1997. Effects of climatic change on hydrological patterns of a forested catchment: a physically based modeling approach, Boreal Environ. Res., 2, 19-31.

Lepistö, A., Seuna, P. and Bengtsson, L., 1994. The environ- mental tracer approach in storm runoff studies in forested catchments, In: FRIEND: Flow Regimes from Experimental and Network Data, Seuna, P., Gustard, A., Arnell, N.W. and Cole, G.A., (eds), Proceedings of the Braunschweig Conference, Oct 1993, IAHS Press, Wallingford, IAHS Publication No. 221, 369-379.

Linsley, R.K., 1976. Rainfall-runoff models. In: Systems Approach to Watershed Modeling, K.A. Biswas (ed), McGraw-Hill, New York, 16-53.

McCarthy, E.J., Flewelling, J.W. and Skaggs, R.W. 1992. Hydrologic model for drained forest watershed, 7. Irrig. Drain. Eng., 118, 242-255.

Merz, B. and Plate, E.J., 1997. An analysis of the effects of spatial variability of soil and soil moisture on runoff, Wat. Resour. Res., 33, 2909-2922.

Mualem, Y., 1976. A new model for predicting the hydraulic conductivity of unsaturated porous media, Wat. Resour. Res., 12, 513-522.

O'Neill, R. 1971. Algorithm AS 47. Function minimization using a simplex procedure. Applied Statistics, 20, 338-345.

Pearce, A.J., Stewart, M.K. and Sklash, M.G., 1986. Storm runoff generation in humid headwater catchments, 1 . Where does the water come from? Wat. Resour. Res., 22, 1263-1272.

Richards, L.A., 1931. Capillary conduction of liquids through porous mediums, Physics, 1, 318-333.

Rodhe, A., 1987. The origin of streammater traced by oxygen-18, Uppsala Univ., Dept. of Physical Geography, Div. of Hydrology, Rep. A 41, 260 p

Seibert, J. 1999. Conceptual runoff models - Fiction or representation of reality. Comprehensive Summaries of Uppsala Dissertations from the Faculty of Science and Technology, 436, Acta Universitatis Upsaliensis, Uppsala, Sweden $52 \mathrm{p}$.

Shuttleworth, W.J., 1992. Evaporation, In: Handbook of Hydrology, Maidment, D.R. (ed), McGraw-Hill Inc.New York, 4.1.-4.53.

Sivapalan, M., Beven, K. and Wood, E.F., 1987. On hydrologic similarity. 2. A scaled model of storm runoff production, Wat. Resour. Res., 23, 2266-2278.

Skaggs, R.W., 1980. A water management model for artificially drained soils, Technical Bulletin, 267, North Carolina Agricultural Research Service, Raleigh, NC, 54 p.

Skaggs, R.W., Karvonen, T. and Kandil, H., 1991. Predicting soil water fluxes in drained lands, $A S A E$, International Summer Meeting, Albuquerque, New Mexico, 23-26 June 1991, Paper 912090 .

Sklash, M.G. and Farvolden, R.N., 1979. The role of groundwater in storm runoff, 7. Hydrol., 43, 45-65.

Todini, E., 1996. The ARNO rainfall-runoff model, 7. Hydrol., $175,339-382$.

van Genuchten, M. Th., 1980. A closed-form equation for predicting the hydraulic conductivity of unsaturated soils, Soil Sci. Soc. Am. 7., 44, 892-898.

Wood, E.F. and O'Connell, P.E., 1985. Real-time forecasting, In: Hydrological Forecasting, Anderson, M.G. and Burt, T.P. (eds.), Wiley, Chichester, UK, 505-558.

Woolhiser, D.A., 1996. Search for physically based runoff model a hydrologic El Dorado? 7. Hydr. Engrg., ASCE, 122, 122-129.

Ye, W., Bates, B.C., Viney, N.R., Sivapalan, M. and Jakeman, A.J., 1997. Performance of conceptual rainfall-runoff models in lowyielding ephemeral catchments, Wat. Resour. Res., 33, 153-166. 